\title{
An Analytical Study of Customer's Satisfaction Level of Different Gender from CRM Process and Customer Care Cell in Banks.
}

\author{
Dr. Dipin Mathur, Apeksha Jain \\ (Associate Professor, Advent Institute of Management Studies, Udaipur, India) \\ (Research Scholar, Mewar University, Gangrar, India)
}

\begin{abstract}
Customer satisfaction from banking services plays crucial role in building a loyal customer base for in all types of banks. So it is very important to study the satisfaction level of the customers from the Customer Relationship Management process of the bank through which they deal. People of different gender have different psychology and perception. Thus, it becomes necessary for every bank to know their customer's satisfaction level to survive in the competitive financial Indian market.

This research paper emphasize on the degree of satisfaction of male and female banking customers from the services under Customer Relationship Management process in the banks where they operate. The paper also aims at finding out the satisfaction of customers of banking industry from the service of customer care cell with respect to solution to their queries.

Keywords: Banks, Customer Relationship Management, Perception, Psychology, Satisfaction.
\end{abstract}

\section{Introduction}

CRM is a one point contact between customer and bank executive. A relationship manager is appointed by most of the banks that use to focus on retention of the customers. Customers are selected by the relationship manager on the basis of deepening in their account. Timely service and quick response leads to increasing rate of retention of customers in the banks. CRM also focus on how the level of service quality affects customer satisfaction. A satisfied customer whether male or female contributes in deepening of transactions. Therefore it is important for a relationship manager to analyze the customer's satisfaction level from the CRM approach adopted by their banks.

\section{Review Of Literature}

Kotler, Jain \& Maesincee (2002) says that CRM is absolutely mentioned as the critical part of many new marketing concepts.

"Committed customers are profitable to an organization for the long term. Customer commitment forms when a customer's expectation is satisfied and the customer realizes fair value from his/her relationship with the organization." Park, C. H., \& Kim, Y. G. (2003)

According to Chaubey, D. S., Joshi, S., \& Zafar, S. T. (2010) "CRM involves new and advance marketing strategies which not only retain the existing customers but also acquire new customers."

"Attainment, regular contact and evaluation of customers direct towards improved customer loyalty (by repeat purchase, positive word of mouth publicity) and employee sentiments." Deshmukh, M. (2012)

According to Kotler, Keller Koshy and Jha (2012), Relationship Marketing aims to build mutually satisfying long-term relationships with key constituents in order to earn and retain their business.

According to Sahoo Rashmita (2013) "CRM has its origin in the basic paradigm of bank marketing, i.e. to satisfy customers with the best possible alternative in the market through a relational exchange process."

\section{Research Methodology}

- Objective of the Study- to Analyze Customer's Satisfaction Level from CRM Process in the Indian Banks.

- Research design- descriptive research design

- Sampling procedure- purposive sampling procedure is followed.

- Procedure for Data Collection- data collection was the next process. It was the most significant and sensitive step in the research process. Data has been collected from Primary and Secondary resources. The primary data was collected through a questionnaire from the respondents. The data collection was done in one phase. Structured questionnaire using multiple choice questions as well as open-ended questions was administered to the respondents. For gathering secondary data various libraries and published sources have been tapped. Data has been collected from books, journals, research papers, websites and academic papers with a view to develop conceptual framework of the study. 
Cross Table 1: Customer's response (males and females) in rating satisfaction level from the CRM process in the banks where they operate their account.

\begin{tabular}{|l|c|c|c|c|}
\hline \multirow{2}{*}{$\begin{array}{c}\text { How would you rate your satisfaction } \\
\text { level }\end{array}$} & \multicolumn{2}{|c|}{ Male } & \multicolumn{2}{c|}{ Female } \\
\cline { 2 - 5 } & $\mathbf{N}$ & $\mathbf{\%}$ & $\mathbf{N}$ & $\mathbf{\%}$ \\
\hline Highly satisfied & 21 & 8.37 & 6 & 5.03 \\
\hline Satisfied & 134 & 53.39 & 87 & 28.86 \\
\hline Somewhat satisfied & 75 & 29.88 & 43 & 8.72 \\
\hline Dissatisfied & 18 & 7.17 & 13 & 0.00 \\
\hline Highly Dissatisfied & 3 & 1.20 & 0 & $\mathbf{1 0 0 . 0 0}$ \\
\hline \multicolumn{1}{|c|}{ Total } & $\mathbf{2 5 1}$ & $\mathbf{1 0 0 . 0 0}$ & $\mathbf{1 4 9}$ & \\
\hline
\end{tabular}

The distribution of data in the above table shows the satisfaction level of customers of banks categorized into male and female. The data reveals that out of male customers $53.39 \%$ are satisfied, $29.88 \%$ are somewhat satisfied and $8.37 \%$ are highly satisfied, $7.17 \%$ are dissatisfied and $1.20 \%$ are highly dissatisfied. Thus majority of customers are satisfied.

While from the female respondents, $58.39 \%$ are satisfied, $28.86 \%$ are somewhat satisfied and $8.72 \%$ are dissatisfied, $4.03 \%$ are highly satisfied and nobody is highly dissatisfied. Thus the same response is there in case of females too as depicted in males.

\section{Cross Table 2: Degree of satisfaction to the customers (males and females) from the response of customer} care cell in solving the queries.

\begin{tabular}{|c|c|c|c|c|}
\hline \multirow{2}{*}{ Response } & \multicolumn{2}{|c|}{ Male } & \multicolumn{2}{|c|}{ Female } \\
\hline & $\mathbf{N}$ & $\%$ & $\mathbf{N}$ & $\%$ \\
\hline Highly satisfied & 3 & 1.20 & 5 & 3.42 \\
\hline Satisfied & 54 & 21.60 & 25 & 17.12 \\
\hline Somewhat satisfied & 97 & 38.80 & 83 & 56.85 \\
\hline Dissatisfied & 89 & 35.60 & 32 & 21.92 \\
\hline Highly Dissatisfied & 7 & 2.80 & 1 & 0.68 \\
\hline Total & 250 & 100.00 & 146 & 100.00 \\
\hline
\end{tabular}

The above table reveals that how satisfied are the customers of bank with customer care cell in the bank for solving their queries. $38.80 \%$ males are somewhat satisfied, $35.60 \%$ males are dissatisfied, $21.60 \%$ are satisfied, $2.80 \%$ are highly dissatisfied and in very rare proportion only $1.20 \%$ are highly satisfied.

With respect to females $56.85 \%$ are somewhat satisfied, $21.92 \%$ are dissatisfied, $17.12 \%$ are satisfied, $3.42 \%$ are highly satisfied and remaining $0.68 \%$ are highly dissatisfied females.

\section{Conclusion}

This conclusion deals with final results derived from the research done in order to justify the satisfaction level of male and female customers of the banks from the CRM process in the banks where they operate their account and role of customer care cell in solving the queries. Thus, the research concludes that more than half of the customers whether male or female dealing with the Indian banks are satisfied with the CRM approach of the banks. Successively the responses also results out that majority of males are somewhat satisfied or dissatisfied with customer care cell in the bank for solving their queries. The female's views are somehow different. It was found that more than half of the female customers are somewhat satisfied with customer care cell in the bank for solving their queries.

\section{References}

Journal Papers:

[1]. Chaubey, D. S., Joshi, S., \& Zafar, S. T. (2010). An Assessment of Customer Relationship Management Practices Opted by Banks for Retaining Customers in Uttrakhand State. International Transactions in Humanities and Social Sciences, July-December., Volume -2, No. - 2, pp. 205-217.

[2]. Park, C. H., \& Kim, Y. G. (2003). A Framework of Dynamic CRM: Linking Marketing with Information Strategy. Business Process Management Journal,9(5), 652-671.

[3]. Sahoo Rashmita (2013). A Study of Customer Perception and Importance of CRM Initiative in the Indian Banking Sector. VSRD International Journal of Business and Management Research, Vol. 3 No. 2 February 2013 / 49.

[4]. Deshmukh, M. (2012). Customer Relationship Management in Indian Commercial Banks. International Journal. Volume 1 Issue 1, October 2012,pg. 10.

Books: 
[5]. Kotler Philip, Keller Kavin Lane, Koshy Abrham and Jha Mithileshwar (2012), Marketing Management, 13th edition. Published by Pearson Education, pg-6,13.

[6]. Kotler, P., Jain, D. C., \& Maesincee, S.S. (2002) Marketing Moves: A New Approach to Profits, Growth, and Renewal.

Internet Link:

[7]. Www.wikipedia.org (2013). “Customer Retention”. Retrieved (2013) from http://en.wikipedia.org/wiki/Customer_retention 